\title{
Utilizing Landsat Satellite Data (1990-2018) to Detect Water Inundation for the Management of Human Settlements in Coastal Zones
}

\author{
Sigit Bayhu Iryanthony', Haeruddin², Muhammad Helmi ${ }^{3}$ and Paul A. Macklin ${ }^{4}$ \\ ${ }^{1}$ Master Program in Aquatic Resource Management, Universitas Diponegoro, Semarang-Indonesia; \\ sigitbayhuiryanthony@gmail.com \\ ${ }^{2}$ Aquatic Resource Department, Fisheries and Marine Science, Universitas Diponegoro, \\ Semarang-Indonesia; haeruddindaengmile@gmail.com \\ ${ }^{3}$ Oceanography Department, Fisheries and Marine Science, Universitas Diponegoro, \\ Semarang -Indonesia; muhammadhelmi69@gmail.com \\ ${ }^{4}$ National Marine Science Centre, Southern Cross University, Coffs Harbour, \\ NSW 2450, Australia; paulmacklin@gmail.com
}

\begin{abstract}
Objective: This study investigates waterinundation in Semarang and Demak and Kendalregencies in Java, Indonesia, utilizingLandsat 5, 7 and 8 satellite imagery, in combination withthe Seamless Digital Elevation Model and National Bathymetry (DEMNAS) data for 50,100 and 150 year projections. Methods: Water inundation detection using optical methods (passive sensors) such as Landsat is an effective tool, more so when combined with the Normalized Difference Water Index (NDWI) method in Green Near Infrared (NIR) bands. Combining imagery from these remote sensing sources with DEMNAS land elevation data may strengthen future water inundation predictions and gauge land loss or degradation in regions subject to land inundation and sea level rise. Findings/Application: Semarang is currently subjected to coastal water inundation associated with losses of coastal infrastructure, resulting in the relocation of human settlements to more elevated areas. Sayung is a sub-distric, the most severely affected sub-district has previously expierienced an increase of water inundationfrom 1434.7ha (1990), 3489.1ha (2002) to4923.8ha (2002), an approximate $1.5 \%$ of land loss annually. This average water inundation increase equivalent to $32 \mathrm{~cm}$ annually is based on DEMNAS data from 1990 to 2018, which may be due to coastal infrastructure which supports inundationin surrounding coastal areas such as Sayung, Demak regency.
\end{abstract}

Keywords: Coastal Management, Land Inundation, Landsat, Normalized Difference Water Index (NDWI), Water Detection

\section{Introduction}

Monitoring coastal water for the future management of coastal zones is vital for management of coastal settlements ${ }^{1}$ and should be considered in regards to effective mitigation and policy ${ }^{2}$. The utilization of multi-temporal satellite imagery data assists in recognizing both spatial dispersion and dynamic changes in the coastal landscape ${ }^{3}$. Satellite data is an effective tool as it provides high resolution product and provides opportunities to monitor temporal variability ${ }^{4}$, while Landsat imagery is a main source of information regarding sea surface changes in the last decades ${ }^{5}$.

Water inundation in the coastal area of north Java is prevalent, particularly in areas with rapidly expanding coastal human settlements. Semarang, in particular, has been subject to increases in episodic flooding, land abrasion and accretion, the degradation of soil surfaces,

${ }^{*}$ Author for correspondence 
and sea water intrusion $\div, 7$, with the natural potential for land loss commonly enhanced by human activities ${ }^{-}$, the main factor being urban structures 9,10 which has been known to promote land subsidence of approximately 19 $\mathrm{cm}$ annually in the Semarang region alone. Semarang is especially prone to sea water intrusion due the topographic geometry of the surrounding coastline. As such, monitoring these coastal zones in densely populated island nations such as Indonesia is necessary for effective management and mitigation ${ }^{11}$. The ability of multi-temporal analysis also plays an important role ${ }^{12}$ in detecting changes in coastal water surface for coastal inundation modeling. For example, previous studies which utilize a Single Band method mix the satellite image water pixels with a different lid $\frac{13}{}$, while the development of NDWI is more compatible with water detection ${ }^{14}$. When combined with high resolution DEM inundation, prediction is strengthened $\frac{15}{5}$, while DEMNAS provides a further increase in resolution $(7 \mathrm{~m})$ necessary for effective monitoring of land loss or degradation.

\section{Study Site}

The port city of Semarang, is the capital of Central Java province, Indonesia $\left(6^{\circ} 58^{\prime} \mathrm{S} 110^{\circ} 25^{\prime} \mathrm{E}\right.$; land area $=373.78$ $\mathrm{km}^{2}$ ) with a human population of 1.8 million people, while the Greater Semarang area has a population of approximately 6 million people. The study areas of investigation include Semarang city, Demark and the district of Kendal (Figure 1), which are particularly prone to coastal water inundation $\frac{16}{}$, episodic flooding ${ }^{17}$ and land subsidence ${ }^{18}$. These combined impacts have already led to human population relocations to more elevated land in Semarang, Demark and Kendal, while impacted landhas been found to be more severe in populated residential areas adjacent to the coast, commonly affected by seawater inundation.

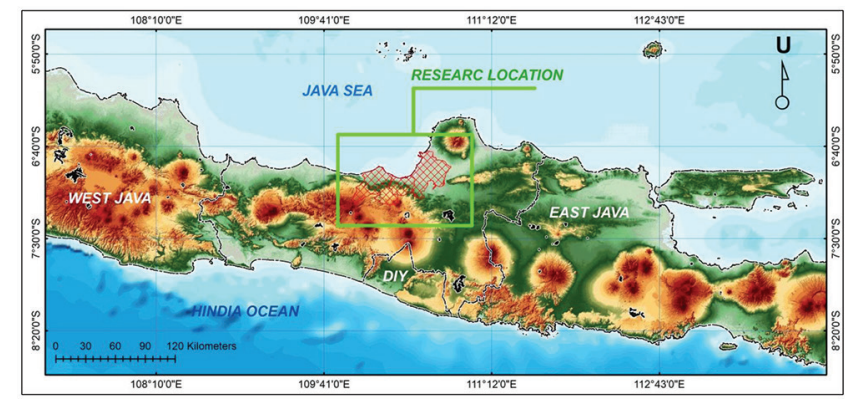

Figure 1. Research area Semarang city, Demakand Kendal district.

\section{Methodology}

Satellite images sourced from 2002, 2010 and 2018 Landsat 5, 7 and 8 product (Table 1) were used for multi-temporal assessments, which were analyzed with QGIS geographic information system software, using correction radiometry and Dark Object Substract (DOS). In addition, image data from Landsat 5 Thematic Mapper (TM; 1990), Landsat 7 with Enhanced Thematic Mapper Plus (ETM+ ; September 2002), and Landsat8Operational Land Imager (OLI; 2018) were integrated for analysis. All Landsat image data was obtained from the United State Geological Survey (USGS) and all product was obtained from dry season months as to avoid cloud interference associated with the Indonesian monsoon season (typically $>80 \%$ cloud cover).

Furthermore, DEMNAS was chosen for its effectiveness in utilizing several data sources such as Interferometric Synthetic Aperture Radar (IFSAR; resolution $=5 \mathrm{~m}$ ), Terra SAR X-band satellite (resolution $=5 \mathrm{~m}$ ) and Phased Array Type L-Band Synthetic Aperture Radar (ALOS PALSAR; resolution $=11.25 \mathrm{~m})$, providing additional resolution by adding mass point stereo-plotting. Spatial data resolution for DEMNAS is 0.27 -arcsecond, using the vertical Earth Gravitational Model (EGM, 2008). For Semarang and surrounding districts, DEMNAS provided a land inundation result with a Root Mean Square Error (RMSE) of $2.79 \mathrm{~m}$, and up to $3.24 \mathrm{~m}$ and $3.71 \mathrm{~m}$ (bias error $=-0.13 \mathrm{~m},-0.63 \mathrm{~m}$ and $2.21 \mathrm{~m}$ respectively) in both DEMNAS and DSM analysis (http://tides.big. go.id/Demnas/).

Satellite water inundation detection from 1990 to 2018 indicated an extensive alteration of coastal area, particularly by surface water in the temporal adjacent coastline. Algorithms to calculate index performance were derived from satellite images using water index normalization, for extraction of surface water from Landsat Data images (1990-2018). The classification of the water margin was approximately determined in our investigations to enable visual interpretation. For Landsat data interpretation of water, we used Near Infrared (NIR) functions; as NIR is absorbed by water and reflected by ${ }^{20}$. Use of data from Landsat4 band were chosen due to its higher band (4) which 1 has previously been effective in distinguishing between water, land and dry areas, while NDWI indicates water as a positive value:

$$
(\mathrm{NDWI})=(\text { Green }-\mathrm{NIR}) /(\text { Green }+ \text { NIR })
$$


Table 1. Effects of water inundation from 1990 to2018 including annual land loss for each sub-district

\begin{tabular}{|c|c|c|c|c|c|c|c|}
\hline Distric & Subdistric & $\begin{array}{c}\text { Area of } \\
\text { Subdistrict } \\
\text { (ha) }\end{array}$ & $\begin{array}{c}1990 \\
\text { (ha) }\end{array}$ & $\begin{array}{c}2002 \\
\text { (ha) }\end{array}$ & $\begin{array}{c}2018 \\
\text { (ha) }\end{array}$ & $\begin{array}{l}\text { Average Land } \\
\text { Loss Per Year } \\
\text { (ha) }\end{array}$ & Percent-age (\%) \\
\hline Demak & Bonang & 8759.2 & 552.2 & 2250.4 & 2802.6 & 80.4 & 0.92 \\
\hline Demak & Karang Tengah & 5539.5 & 151.1 & 885.5 & 1036.6 & 31.6 & 0.57 \\
\hline Demak & Sayung & 8611.4 & 1434.7 & 3489.1 & 4923.8 & 124.6 & 1.45 \\
\hline Demak & Wedung & 12878.0 & 73.0 & 1391.6 & 1464.6 & 49.7 & 0.39 \\
\hline Kendal & Brangsong & 3236.5 & 104.6 & 248.5 & 353.0 & 8.9 & 0.27 \\
\hline Kendal & Cepiring & 2492.7 & 38.5 & 456.9 & 495.4 & 16.3 & 0.65 \\
\hline Kendal & Kaliwungu & 9342.6 & 209.7 & 1764.5 & 1974.2 & 63.0 & 0.67 \\
\hline Kendal & Kangkung & 3552.0 & 13.5 & 430.2 & 443.7 & 15.4 & 0.43 \\
\hline Kendal & Kota Kendal & 3121.2 & 52.0 & 644.4 & 696.4 & 23.0 & 0.74 \\
\hline Kendal & Patebon & 4372.2 & 129.9 & 1152.8 & 1282.7 & 41.2 & 0.94 \\
\hline Kendal & Rowosari & 2975.6 & 1.1 & 47.3 & 48.3 & 1.7 & 0.06 \\
\hline Kota Semarang & Gayamsari & 612.8 & 2.1 & 72.1 & 74.2 & 2.6 & 0.42 \\
\hline Kota Semarang & Genuk & 2756.6 & 72.0 & 722.0 & 793.9 & 25.8 & 0.94 \\
\hline Kota Semarang & Semarang Barat & 2222.8 & 127.6 & 652.4 & 780.0 & 23.3 & 1.05 \\
\hline Kota Semarang & Semarang Tengah & 535.4 & 0.0 & 46.7 & 46.7 & 1.7 & 0.31 \\
\hline Kota Semarang & Semarang Timur & 559.5 & 6.2 & 88.4 & 94.6 & 3.2 & 0.56 \\
\hline Kota Semarang & Semarang Utara & 1072.9 & 57.9 & 465.4 & 523.4 & 16.6 & 1.55 \\
\hline Kota Semarang & Tugu & 3008.7 & 121.8 & 1848.2 & 1970.0 & 66.0 & 2.19 \\
\hline
\end{tabular}

\section{Mapping Water Inundation}

Water inundation points were calculated using a Geographic Information System (GIS), utilizing the raster function, which highlights roads and the boundaries, while water inundation data from Landsat imagery provided multi-temporal references. DEMNAS was used for mapping future water inundation projections, enabling modeling of water inundation with high accuracy, indicating present flooding of residential areas, in addition to its predictive potential. The former predictive potential may assist future planning and mitigation, more-so when combined with current regional urban planning (RTRW) in the Semarang and surrounding municipalities, which currently do not account for human settlement relocation which derive from land loss or degradation as a result of increasing water inundation events.

Landsat is very efficient in detecting land loss using multi temporal analysis. The results of Landsat data were acquired using Band 6 (SWIR), Band 5 (NIR), Band 4 (RED) from Landsat 8, and Band 5 (SWIR),
Band 4 (NIR), and Band 3 (RED) from Landsat 7. For Landsat 5 analysis we used a combination of Band 5 (SWIR), Band 4 (NIR) and Band 3 (RED). This combination allowed more precise differentiations between land and water. This indicated the broad changes in coastal land loss from 1990, with increased water inundation in 2002 and increasing, particularly in the surrounding sub-districts of Sayung and Demak in 2002 forwards.

The method of normalization when differentiating, water is very efficient when performing comparative analysis with water inundation and the optical image. The green bandis particularly effective in emphasizing vegetation, and assessing vegetation health, while NIR is effective in assessing vegetation biomass and coastal shoreline changes, especially pronounced in the Sayung sub-district and Demak. Figures 2 and 5 highlight how water inundation, and resulting large volumes of surface water runoff, has affected Sayung, more-so than other areas in the region, as Sayung is dependent on its aquaculture industry and thusis subjected to economic pressures. 


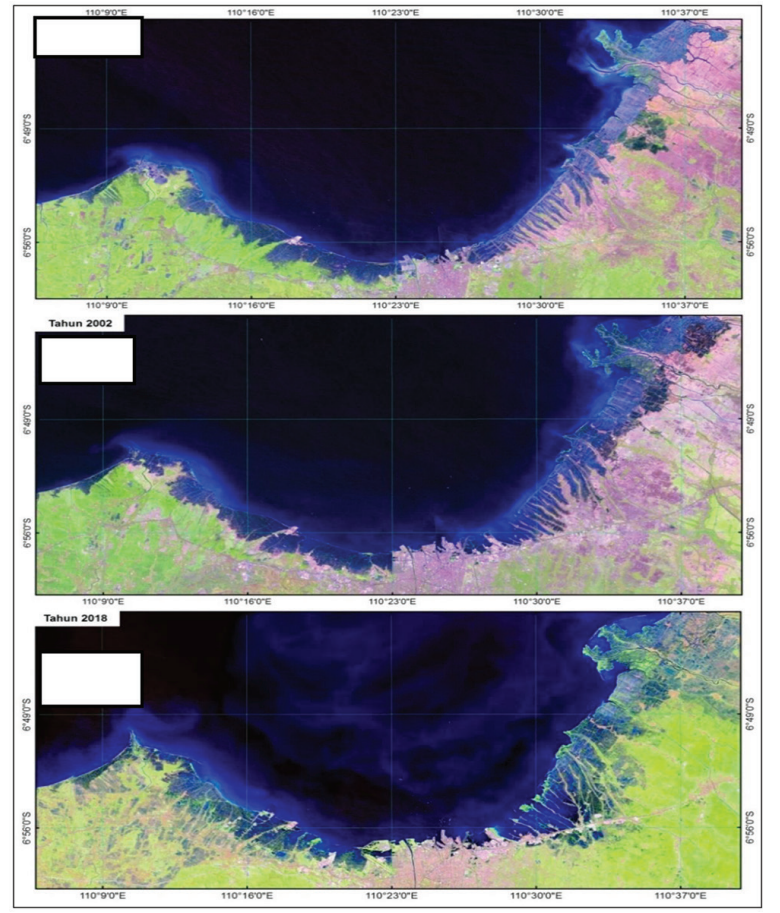

Figure 2. Landsat imagery in: A. 1990, B. 2002, and C. 2018 showing increase of water inundation in the Semarang region.

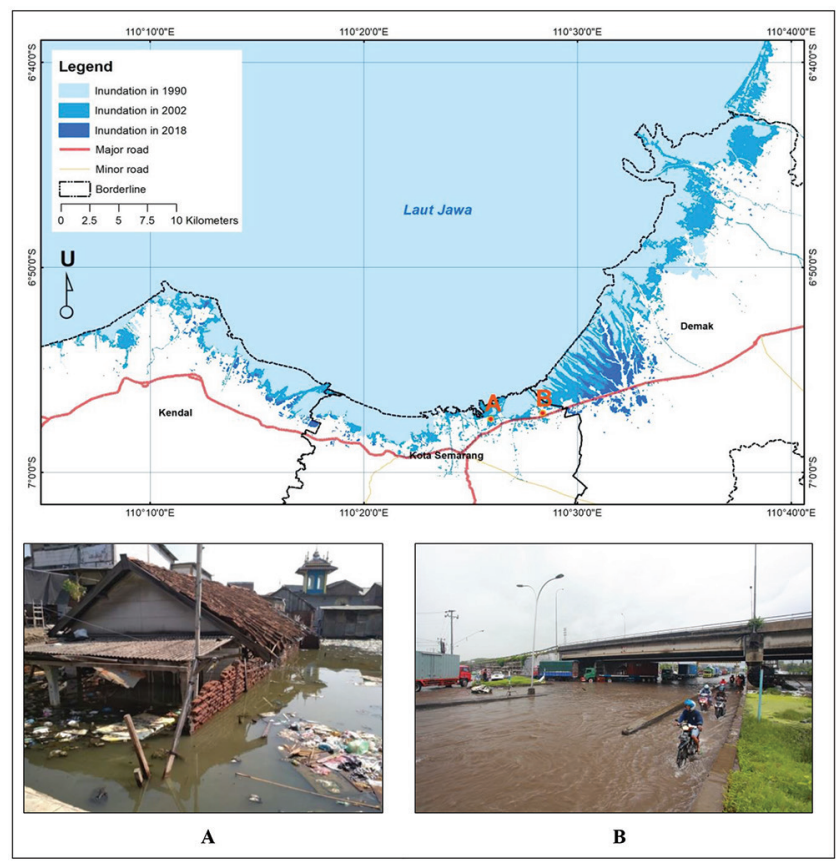

Note: A. is an example of the condition in location 1 , B. an example of the condition in location 2.

Figure 3. A colour-coded representation of water inundation of the investigated area in 1990, 2002 and 2018.

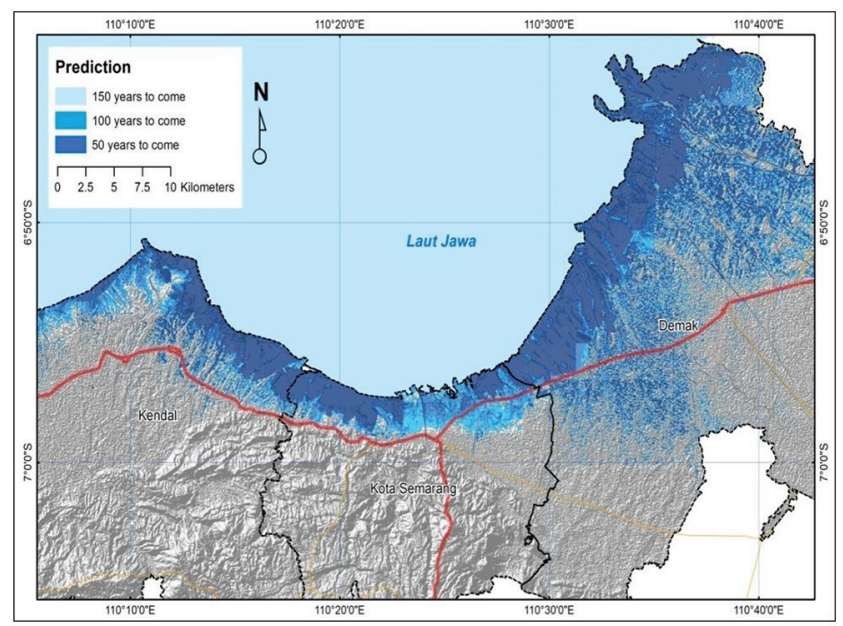

Figure 4. Water inundation prediction for 50, 100, and 150 years for Semarang, Kendal and Demark based on DEMNAS analysis.

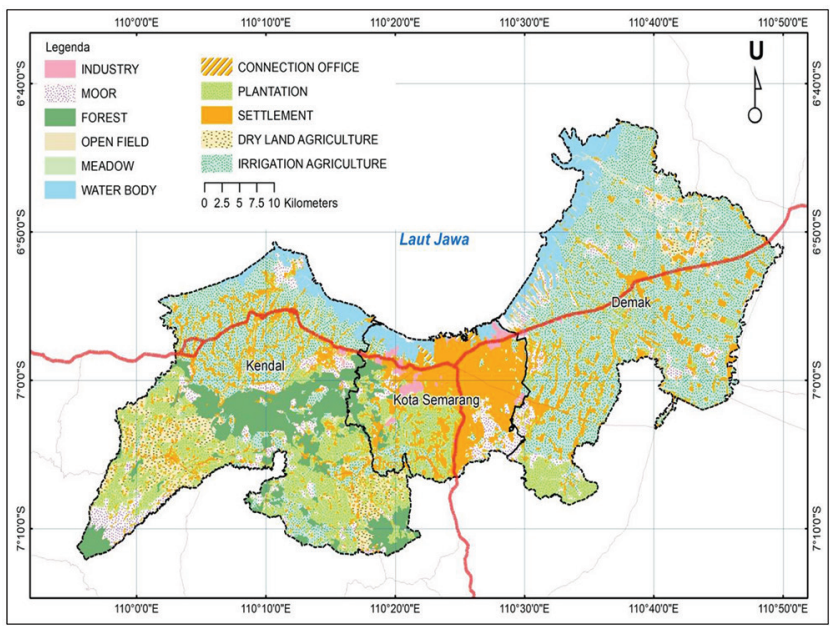

Source: Semarang City Government.

Figure 5. Landuse map for Semarang, Demak and Kendal district.

\section{Discussion}

The ability of the Landsat satellite is indeed very profitable in research to detect the water body. Landsat with multitemporal of benefits also selects the data to be processed. The data weakness of Landsat optics which is vulnerable to the atmospheric conditions. The tropical regions such as Indonesia are very dynamic in atmospheric changes (clouds cover), especially the changes in the rainy months. The satellite data will be very hard use when the cloud covers are in the study areas the utilisation of the method water index will be very difficult 
to differentiate between the huge volumes of runoff, water in the region of wet rice farming, and tidal flood. The detection of highly effective water bodies without cloud cover can be done with Synthetic Aperture Radar (SAR)21 with the airborne survey method, but it is very expensive. The use of SAR spaceborne vehicles has also been widely used in the detection of floods ${ }^{22}$. Currently the European consortium provides free sentinel 1A-B SAR data, but recording began in late 2014 . The same thing was done by the Alaska satellite facility providing access to Alos Palsar 1 data. Multitemporal analysis is still difficult because of the different platforms and types of sensors used. This is an advantage of using Landsat in long multi-temporal analysis.

\section{Conclusion}

Utilization of Landsatdata is very beneficial in modeling water inundation. Multi-temporal analysis also greatly assists with future water inundation spatial mapping, however, has lacked in combining other methodology such as SAR methodology which is effective in denser cloud cover. Landsat is thus an ideal image product for monitoring land loss or degradation resulting from water inundation.

\section{References}

1. Lu S, Wu B, Yan N, Wang H. Water body mapping method with HJ-1 A / B satellite imagery, International Journal of Applied Earth Observation and Geo-information. 2011; 13(3):428-34. https://doi.org/10.1016/j.jag.2010.09.006.

2. Giardino C, Bresciani M, Villa P, Martinelli A. Application of Remote Sensing in Water Resource Management: The Case Study of Lake Trasimeno, Italy; 2010. p. 3885-86. https://doi.org/10.1007/s11269-010-9639-3.

3. Wulder MA. Land cover 2.0, International Journal of Remote Sensing. 2018; 39(12):4254-84. https://doi.org/10. 1080/01431161.2018.1452075.

4. Ji L, Zhang L, Wylie B. Analysis of dynamic thresholds for the normalized difference water index, Photogrammetric Engineering and Remote Sensing. 2009; 5(11):1307-17. https://doi.org/10.14358/PERS.75.11.1307.

5. Rokni K, Ahmad A, Selamat A, Hazini S. Water feature extraction and change detection using multitemporal landsat imagery, Remote Sensing. 2014; 4173-89. https:// doi.org/10.3390/rs6054173.
6. Hadi S. In search for sustainable coastal management: a case study of Semarang, Indonesia, Journal of Physics: Conference Series. 2016; 755:11001.

7. Marfai MA, King L. Potential vulnerability implications of coastal inundation due to sea level rise for the coastal zone of Semarang city, Indonesia, Environ. Geol. 2008; 54(6):1235-45. https://doi.org/10.1007/s00254-007-0906-4.

8. Feyisa GL, Meilby H, Fensholt R, Proud SR. Remote sensing of environment automated water extraction index : A new technique for surface water mapping using Landsat imagery, Remote Sensing Environment. 2014; 140:23-35. https://doi.org/10.1016/j.rse.2013.08.029.

9. Abidin HZ, Andreas H, Gumilar I, Sidiq TP, Fukuda Y. Land subsidence in coastal city of Semarang (Indonesia): Characteristics, impacts and causes, Geomatics, Nat. Hazards Risk. 2013; 4(3):226-40. https://doi.org/10.1080/1 9475705.2012.692336.

10. Gumilar I, Abidin HZ, Andreas H, Mahendra AD, Sidiq TP, Gamal M. Studi Potensi Kerugian Ekonomi (Economic Losses) Akibat Penurunan Muka Tanah (Studikasus: Wilayah Jakarta, Bandung dan Semarang), Kelompok Keilmuan Geodesi, Institut Teknologi Bandung. 2009.

11. Marfai MA. The hazards of coastal erosion in Central Java. Indonesia: An overview, GEOGRAFIA Online Malaysia Journal of Society and Space. 2011; 7(3):1-9. http://journalarticle.ukm.my/2355/1/1.2011-3-MARFAI_ ugm-english-1\%5B1\%5D_-_edited_28.8.pdf.

12. Justice CO, Townshend JRG, Holben BN, Tucker CJ. Analysis of the phenology of global vegetation using meteorological satellite data, International Journal of Remote Sensing. 2013; 37-41.

13. Du Z. Estimating surface water area changes using timeseries Landsat data in the Qingjiang River Basin, China, International Journal of Remote Sensing. 2012. https://doi. org/10.1117/1.JRS.6.063609

14. Mcfeeters SK. The use of the Normalized Difference Water Index (NDWI) in the delineation of open water features, International Journal of Remote Sensing. 1996; 17(7): 1425-32.

15. Hawker L, Rougier J, Neal J, Bates P, Yamazaki D. Implications of simulating global digital elevation models for flood inundation studies, Water Resources Research. 2018; 54(10):7910-28. https://doi.org/10.1029/2018WR023279.

16. Buchori I, Pramitasari A, Sugiri A, Maryono M, Basuki Y, Sejati AW. Adaptation to coastal flooding and inundation: Mitigations and migration pattern in Semarang City, Indonesia, Ocean Coast. Management. 2017; 163:445-55. https://doi.org/10.1016/j.ocecoaman.2018.07.017.

17. Setyani RE, Saputra R. Flood-prone areas mapping at Semarang City by using simple additive weighting method, 
Procedia - Social and Behavioral Sciences. 2015; 227:37886. https://doi.org/10.1016/j.sbspro.2016.06.089.

18. Husnayaen. Physical assessment of coastal vulnerability under enhanced land subsidence in Semarang, Indonesia, using multi-sensor satellite data, Advances Space Research. 2018; 61(8):2159-79. https://doi.org/10.1016/j. asr.2018.01.026.

19. Buchori I, Sugiri A, Mussadun M, Wadley D, Liu Y. A predictive model to assess spatial planning in addressing hydro- meteorological hazards: A case study of Semarang City, Indonesia, International Journal of Disaster Risk Reduction. 2017. https://doi.org/10.1016/j. ijdrr.2017.11.003.
20. Sun F, Sun W. Comparison and improvement of methods for identifying water bodies in remotely sensed imagery, International Journal of Remote. 2012; 37-41.

21. Oberstadler R, Hönsch H, Huth D. Assessment of the mapping capabilities of ERS-1 SAR data for flood mapping: A case study in Germany, Eur. Sp. Agency. 1996; 11(383):247-52. https://doi.org/10.1002/(SICI)10991085(199708)11:10<1415::AID-HYP532>3.0.CO;2-2.

22. Yan K, Di Baldassarre G, Solomatine Dp, Schumann GJ. A review of low-cost space-borne data for flood modelling: Topography, flood extent and water level, Hydrological Process. 2015; 29(15). https://doi.org/10.1002/hyp.10449. 